\title{
Interview with Jörg Lübcke on "Digitalization of Business Models in the Media Industry"
}

Dr. Jörg Lübcke has been the managing director of Burda Digital GmbH since 2010. The business area Digital of Hubert Burda Media combines the strategic Internet activities of the Group. It includes e-commerce companies and marketing platforms, as well as companies in direct marketing, customer management, referral platforms as well as social media and corporate venture investments. The share of the digital division of group sales amounted to over EUR 1 billion in 2012, thus providing almost half of Hubert Burda Media's total sales. Before joining Hubert Burda Media, Dr. Jörg Lübcke worked as a member of the management of the international consulting firm Booz \& Company and as Vice President at Giesecke \& Devrient $\mathrm{GmbH}$. Dr. Lübcke studied economics with a focus on finance and management at the Free University of Berlin, where he received his doctorate.

DOI 10.1007/s12599-013-0269-1

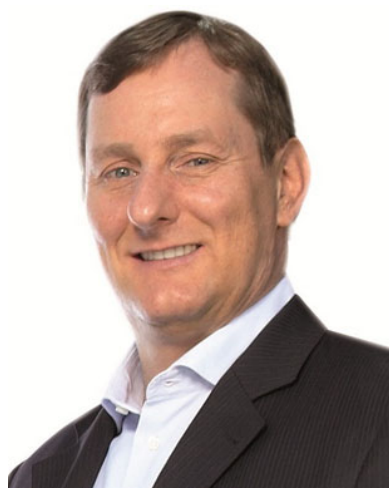

Dr. Jörg Lübcke Managing Director Burda Digital GmbH Arabellastrasse 23 81925 München Germany joerg.luebcke@burda.com http://www.hubert-burda-media.de

\section{Interview by}

Prof. Dr. Martin Spann ( $\varangle)$ Institut für Electronic Commerce und Digitale Märkte

Ludwig-Maximilians-Universität München Geschwister-Scholl-Platz 1 80539 München Germany spann@bwl.Imu.de http://www.ecm.bwl.Imu.de

Published online: 2013-04-26
This article is also available in German in print and via http://www. wirtschaftsinformatik.de: Spann M. (2013) Interview mit Jörg Lübcke zum Thema „Digitalisierung der Geschäftsmodelle in der Medienindustrie". WIRTSCHAFTSINFORMATIK. doi: 10.1007/s11576-013-0364-4.

(C) Springer Fachmedien Wiesbaden 2013

BISE: What are the challenges arising from digitalization of business models in the media industry?

Lübcke: The concrete details of business models in the media industry depend strongly on the technology employed. Taking the example of traditional publishing, it is printing on paper. The characteristics of these technologies on the one hand and the customer needs on the other hand induce the publishers' options for creating, bundling, curating, and distributing content. Digitalization changes or enhances these technological conditions. The same customer needs can now be addressed with other formats and, by other market players than traditional print-publishers. I am convinced that well made print formats that meet the customer needs will continuously be published successfully. It will be increasingly difficult for products that owe their existence merely to the limitations of legacy technologies. Moreover, new technologies (e.g., social networks, mobile applications, localization, big data, and tablet pc's) give the publishers a chance to extend their business model. However, as a precondition, the features of the new technologies must be understood and mastered. In the medium term it will not be sufficient to simply push existing content to the Internet. The challenge for media businesses lies in finding out the opportunities associated with new technologies.

BISE: The revenues of onlineadvertising are less than those of print products. Mobile access with smaller displays is increasing. How solid will advertising-based business models be in the future?

Lübcke: The market for online advertising revenues has become larger than that for print advertising revenues. But a direct comparison is difficult. Google's dominant role has led to the situation that currently on the Internet almost only transaction-oriented advertisement can be financed successfully. Thereby, the business model of content provision financed by brand advertisement is hardly economically feasible any more. However, it could be a successful way for media companies if they manage to base the digital media offerings more on transaction-oriented business models. As a result, they can successfully draw earnings from good content in both areas, offline and online. CHIP is a good example. Both the print product and the online platform are marketed successfully. On the Internet, however, the revenues are generated from a mixture 
of display advertising and transactionoriented offerings, such as product tests, price comparison, or software download. If and how ad-financed business models can be established in mobile communication is hard to guess at the moment. The trend towards mobile devices leads to disruptive effects in wide ranges of net based and offline areas. One might say, the (online-) revolution is turning against its own children. Already now, traffic growth on the Internet is largely attributed to the extended use of mobile devices. With the shift from desktop and laptop computers to smart phones and tablet pc's, the supply structure in the consumer electronics field is changing significantly. The latter devices are fungible worldwide since, e.g., they have no country-specific keyboards. This affects the already small margins of online retailers. Mobile devices are true "personal computers". Wherever the user may be - the device is also there. Thereby, the context changes, and the usage characteristics of online services or the offerings themselves are changing. Instead of large websites with many categories, we find more application-oriented apps for specific and often localized situations. E.g., price comparisons are increasingly invoked at the point of sale. By taking a snapshot or scanning a barcode, the shopper can search for prices of the individual article. The changed usage of mobile devices also brings along new ways of monetizing. Currently the mobile advertisement revenues are lower than online advertising revenues. I suppose, however, that this will change within the next one to two years. On the one hand new advertisement formats will emerge, and on the other hand mobile advertisement will become clearly closer to transactions and therefore more profitable.

BISE: How do you assess efforts and success of pay models for media content?

Lübcke: The success of pay models will depend on the added value represented by the media content. The more unique and desired the content is the more customers will be willing to pay. Simply making existing content available on the Internet subject to a charge reminds somewhat of the early automobiles that looked like horse carriages. The new technologies will also define anew the essence of media content and in which form it may be economical. But this requires that the media enterprises can master and design the new technologies.
BISE: Where do you see the synergetic potential between media business and e-commerce business models? For which e-commerce business models would media enterprises be the best owners?

Lübcke: It would be interesting to invert the question. What is in fact the difference between information offerings (=media) and product offerings (=e-commerce) on the Internet? As an example, CHIP informs on numerous consumer electronics products, maintains one of the largest test centers in Europe, a large database on product features, and the leading download platform. After a customer has obtained information on a device via CHIP, why shouldn't we also give him the option to initiate a purchase? This makes even more sense since customers already do download software via CHIP very often. In contrast to print media, on the Internet we can initiate transactions immediately. At this point the already mentioned relationship of print media and technology comes into play. As long as the production of media content is tied to printing on paper, limitations remain that have nothing to do with customer needs. Burda has encountered during recent years that users and customers wish and value the multi-modality of value creation. Our subsidiary Holidaycheck is the electronic version of a travel magazine, written by customers and curated by the publishing house. But the customers who gather information on hotels also wish to be able to book their trip in the same environment. Therefore, Holidaycheck has built a transaction-oriented offering, informs about vendors and prices of travel offers, and if desired connects the customers to the respective travel agencies. Consequently Holidaycheck is today one of the largest travel brokers on the Internet. The question for what type of offers media enterprises are the best owners has to do, in my opinion, both with experience and DNA of media enterprises. More than 12 years ago, Burda began to invest into young Internet companies. Over time we have developed a large contact network and a wealth of experience regarding the spotting and guiding of suitable firms, including sustainable supervision, assistance, and development. In this context a major role is taken by the conference Digital Life Design (DLD). Basically, successful media enterprises like Burda understand their readers' needs and can cover them with high professionalism, passion, and commitment. Only if one knows and understands the customer needs, one can produce successful journals for the target groups. But if one understands the customer needs, and if they exceed mere information, then one can and should exploit this core competency in order to serve the customers as best as possible. For Hubert Burda Media this means that in principle all business models on the Internet are suitable to fulfill this precondition of closeness to the consumer.

BISE: How can new technological options such as big data or smart phones/ location-based services be exploited by media enterprises, respectively can they be regarded as opportunities?

Lübcke: The better a company knows the customer's needs and circumstances the better it can adjust its offerings. Both technologies, big data and location-based services, can support this. The analysis of large data volumes and the knowledge on the context of information search facilitate new or extended offers to the customer. If the customer wishes, targetoriented Information on a desired product can be given at the point of sale, or he can receive hints to physicians in the proximity, etc. Smart phones are the devices that supply geographical data and form the basis of location-based services.

BISE: What does digitalization require from future employees?

Lübcke: Hubert Burda Media generates currently more than half of the revenues from the digital area and is growing in double figures. For this transformation process, from a publisher to a broad media company, we need employees with diverse qualifications. Besides traditional positions, like printers, management assistants, and journalists, many new positions have been added: programmers, developers, entrepreneurs, on national and international scale. Diversity is a buzzword that expresses the Hubert Burda Media's multifariousness. As a matter of fact, only our claim to hire and develop the best people in the respective field has remained the same.

BISE: How can German-based companies exploit the potential of digitalization even better?

Lübcke: The fundamental characteristic of the Internet is networking. And this is in my opinion also the chance for better exploitation of digitalization. In order to strengthen Germany as digitalization location, Hubert Burda Media has teamed up in the Internet Business 
Cluster with the Ludwig-MaximiliansUniversität Munich, the University of Regensburg, and other renowned firms such as ProSiebenSat1.Digital, Tomorrow
Focus und SapientNitro. The cooperation's goal is the support of research and teaching in the digital field, and a related stronger networking of all stakeholders in digital business, in order to advance Germany as a digitalization location.

BISE: Dr. Lübcke, thank you very much for the interesting interview. 